\title{
EFFECT OF SPRAYING ZINC, COPPER AND IRON ON LEAF NUTRIENT, FRUIT SET AND SOME FRUIT QUALITY OF PISTACHIO TREES (Pistacia vera L.) CV. HALEBI
}

\author{
ZULAIKHA RAMADHAN IBRAHIM \\ Dept. of Horticulture, College of Agricultural Engineering Sciences, University of Duhok, \\ Kurdistan Region - Iraq
}

(Received: November 11, 2020; Accepted for Publication: December 12, 2020)

\begin{abstract}
This study was conducted at a private orchard in the Ekmale village of Duhok Governorate, Kurdistan Region, Iraq during growing season (2020) to evaluate the effect of foliar sprays of three concentrations of zinc $\left(0,750\right.$, and $\left.1500 \mathrm{mg} . \mathrm{L}^{-1}\right)$, three concentrations of copper $\left(0,100\right.$, and $\left.200 \mathrm{mg} . \mathrm{L}^{-1}\right)$ and three concentrations of iron $\left(0,150\right.$, and $\left.300 \mathrm{mg} . \mathrm{L}^{-1}\right)$ on leaf nutrient, fruit set, as well as yield and quality of 18years old " Halebi " pistachio trees. The nutrition solutions were sprayed on trees at two times (bud swell stage and green tip stage). Based on the obtained results, fruit set percentage, yield, and leaf nutrient were significantly affected by foliar application of a zinc, copper and iron each alone. In combination, the triple interactions among $1500 \mathrm{mg} . \mathrm{L}^{-1}$ zinc plus $200 \mathrm{mg} . \mathrm{L}^{-1}$ copper and $300 \mathrm{mg} . \mathrm{L}^{-1}$ iron was the most affected one which exceed significantly on the control treatment, Moreover, nutrient treatment had a significant effect on the percentage of blankness. In general, these results show that $\mathrm{Zn}, \mathrm{Cu}$ and Fe fertilizers is necessary for obtaining better yield and fruit quality in " Halebi " pistachio trees.
\end{abstract}

\section{INTRODUCTION}

$\mathbf{P}$ istachio (Pistacia vera L.), is a subtropical, dioecious, drought-tolerant species, which well-adjusted to arid and semiarid regions (Javanshah et al., 2005; Einali and Valizadeh, 2017). Although, the soil in which pistachio grown is often poor and related with high calcium carbonate content and alkaline $\mathrm{pH}$ and restricted accessibility of some nutrients causing suffering of pistachio trees from many minerals' deficiencies (Tavalli and Rahemi, 2007). Hence, addition of fertilizers to complement the natural soil fertility is important for modern crop production, and accurate management of nutrient elements is essential for a sustainable agriculture production.

Lately as a result of some deficiency in micro elements in some pistachio area of production, low fruit set can be seen in many orchards (Mozafari 2005). One reason of low fruit set can be deficiency of zinc, copper, iron (Gursoz et al., 2010) and some other elements, as fruit set is an important component of yield (Rosati et al., 2010). Micro-nutrients such as iron, zinc and copper are fundamental for different biological functions that might be ascribed to tree yield and fruit quality (Shoeib and El sayed 2003).
Zinc $(\mathrm{Zn})$ is regarded as fundamental in plants because of its worth in the activity of many enzymes, and it helps with cell division, photosynthesis, and the synthesis of tryptophan and proteins (Wang et al., 2016). Moreover, foliar applications of $\mathrm{Zn}$ have been effectively used to increase tree vigor, fruit set, and yield in walnut (Keshavarz et al,.2011). Furthermore, spraying of Zinc significantly increased yield in various pistachio cultivars through increasing fruit set. Also, enhanced physical and chemical fruit properties as well as leaf content of $\mathrm{Zn}$ and Mn, (Gursoz et al., 2010).

Copper $(\mathrm{Cu})$ assume a significant part in the metabolism of plants and furthermore has a function in many cellular processes and is a basic ligand for the activities of specific enzymes which are important in cell growth and differentiation. Various studies have demonstrated that mineral foliar applications, particularly of zinc and copper, are gainful as for yield, fruit quality, nutritional status, and fruit set. Research has verified that this is the situation with fruit crops, as pistachio (Kallsen et al. 2000; Kizilgoz, et al., 2010).

Iron $(\mathrm{Fe})$ is necessary for the synthesis and upkeep of chlorophyll in plants. It is an essential component of many enzymes and assume an imperative function in nucleic acid and 
chloroplast metabolism. So, deficiency of this element decreased the photosynthesis which causes huge losing in fruit yield (Chaturvedi et al., 2005). In addition, iron deficiency is a usual disorder influencing plants in many regions of the world, and is predominantly connected with high $\mathrm{pH}$, calcareous soils. Plant Fe deficiency has economic significance, as crop quality and yields can be severely become compromised, and the use of costly restorative techniques is regularly required (Alvarez-Fernandez et al. 2004). Research found by (Najad 2004) showed that pistachio fruit quality increased with foliar Fe fertilization.

Therefore, the aims of this study were to determine the effect of foliar spraying of zinc, copper and iron on leaf nutrient, fruit set and yield of " Halebi " pistachio trees.

\section{MATERIALS AND METHODS}

The experiment was carried out on pistachio trees (cv. Halebi) 18 years of age, in (2020) in Ekmale private orchard. The position of this area is $\left(36.92^{\circ}\right)$ north and $\left(43.046^{\circ}\right)$ east at an elevation of (845) meters above sea level. This orchard considered as rainfed orchard. The experiment was designed as a $3 \times 3 \times 3$ factorial experiment in a Randomized Complete Block Design (RCBD). Zinc treatment, was supplied from zinc sulfate source in three level $(0,750$, and $1500 \mathrm{mg} . \mathrm{L}^{-1}$ ), copper was supplied from copper sulfate source in three level $(0,100$, and $200 \mathrm{mg} . \mathrm{L}^{-1}$ ) and iron was supplied from iron sulfate source in three level $(0,150$, and 300 $\mathrm{mg} . \mathrm{L}^{-1}$ ).

The nutrition solutions were sprayed on trees at two times (bud swell stage and green tip stage). The experiment consisted of 27 treatments with three replications and one tree for each experimental unit (81trees). Trees were hand sprayed to the point of runoff with treatment solution and Tween 20 was used as a surfactant. All the data were tabulated and statistically analyzed with computer using SAS program. The differences between various treatment means were tested with Duncan Multiple Range test at 5\% level (SAS, 2015). For fruit set, four branches (from different direction of each tree) were randomly selected for each treatment. Flowers on the labeled shoots were counted at the (middle of April). For the primary fruit set\%, fruit on the shoots were counted at the time of post-bloom (early of May), and fruit set percentage was calculated according to the following equation:

Primary fruit set $(\%)=[$ No. of fruit (post bloom) / Total no. of flower] $\times 100$

Final fruit set\% was estimated by dividing the number of fruit determined after harvesting by the total number of flowers:

Final fruit set $(\%)=[$ No. of fruit after harvesting / Total no. of flower] $\times 100$

For yield and yield component, all pistachio clusters were removed from the labeled branches of the tree by hand, when the fruit reached the stage of physiological maturity, signaled by a reddish hull (end of August), fresh yield per shoot for each treatment was determined by means of weighing clusters. In addition, the number of blank nuts was determined from samples of 100 nuts taken randomly and evaluated as a percentage (Soliemanzadeh, 2012).

To determine the mineral concentration of the leaves, dry matter of the leaves was used in the chemical analysis $0.5 \mathrm{~g}$ from each experimental unit was digested with diacid H2SO4.The previously dried samples were used to determine leaf zinc, copper and iron content. $0.5 \mathrm{~g}$ of leaf dry matter from each experimental unit was digested by using $(10 \mathrm{ml})$ concentrated sulphuric acid (diacid $\mathrm{H}_{2} \mathrm{SO}_{4}$ ) and $5 \mathrm{ml}$ hydrogen peroxide $\left(\mathrm{HClO}_{4}\right)$ and the Inductively Coupled Plasma ( ICP-OES 7000) was used (Bhargava and Raghupathi, 1993).

\section{RESULTS AND DISCUSSIONS \\ 1- Leaf Nutrient \\ 1- Zinc content in leaves (mg.kg-1)}

Table (1) explained that the spraying Halebi pistachio trees with $1500 \mathrm{mg} . \mathrm{L}^{-1}$ zinc, $200 \mathrm{mg} . \mathrm{L}^{-1}$ copper with $300 \mathrm{mg} . \mathrm{L}^{-1}$ iron significantly increased zinc content in leaves which gave the highest value (14.90, 14.59 and 14.26 mg. $\mathrm{kg}^{-1}$ ) respectively.

Results indicated that the triple interaction of $1500 \mathrm{mg} . \mathrm{L}^{-1}$ zinc, $200 \mathrm{mg} . \mathrm{L}^{-1}$ copper with $300 \mathrm{mg} . \mathrm{L}^{-1}$ iron gave the highest value $(16.37$ $\left.\mathrm{mg} \cdot \mathrm{kg}^{-1}\right)$ compared to lowest value $\left(10.46 \mathrm{mg} \cdot \mathrm{kg}^{-}\right.$ ${ }^{1}$ ) from the interaction of $0 \mathrm{mg} . \mathrm{L}^{-1} \mathrm{zinc}, 0 \mathrm{mg} \cdot \mathrm{L}^{-1}$ copper and $0 \mathrm{mg} . \mathrm{L}^{-1}$ iron 
Table (1): Effect of Foliar Spraying of Zinc, Copper and Iron and their interactions on zinc content in leaves $\left(\mathrm{mg.kg}^{-1}\right)$ of pistachio cv. "Halebi"

\begin{tabular}{|c|c|c|c|c|c|c|}
\hline \multirow[t]{2}{*}{ Zinc mg.L-1 } & \multirow[t]{2}{*}{ Copper mg.L-1 } & \multicolumn{3}{|c|}{ Iron mg.L-1 } & \multirow[t]{2}{*}{ Zinc $\times$ Copper } & \multirow[t]{2}{*}{ Means of Zinc } \\
\hline & & 0 & 150 & 300 & & \\
\hline \multirow[t]{3}{*}{0} & 0.0 & $10.46 p$ & 11.600 & $12.46 \mathrm{I}-\mathrm{n}$ & $11.51 \mathrm{e}$ & $12.56 \mathrm{c}$ \\
\hline & 100 & $12.34 \mathrm{~m}-\mathrm{o}$ & 12.50I-n & $12.70 \mathrm{k}-\mathrm{n}$ & $12.51 d$ & \\
\hline & 200 & $13.24 \mathrm{i}-I I$ & $13.54 \mathrm{~g}-\mathrm{j}$ & $14.23 \mathrm{c}-\mathrm{g}$ & $13.67 \mathrm{c}$ & \\
\hline \multirow[t]{3}{*}{750} & 0 & 12.18no & $13.14 \mathrm{i}-\mathrm{m}$ & $13.37 \mathrm{~h}-\mathrm{k}$ & $12.90 \mathrm{~d}$ & $13.65 b$ \\
\hline & 100 & 12.91j-n & $13.71 f-j$ & $14.15 \mathrm{c}-\mathrm{g}$ & $13.59 \mathrm{c}$ & \\
\hline & 200 & $13.95 \mathrm{~d}-\mathrm{i}$ & $14.38 \mathrm{~b}-\mathrm{g}$ & $15.10 \mathrm{~b}$ & $14.48 b$ & \\
\hline \multirow[t]{3}{*}{1500} & 0 & $13.82 \mathrm{e}-\mathrm{i}$ & $14.47 \mathrm{~b}-\mathrm{e}$ & $14.95 \mathrm{bc}$ & $14.41 \mathrm{~b}$ & $14.90 \mathrm{a}$ \\
\hline & 100 & $14.28 \mathrm{~b}-\mathrm{g}$ & $14.76 b-d$ & $14.97 \mathrm{bc}$ & $14.67 \mathrm{~b}$ & \\
\hline & 200 & $14.58 \mathrm{~b}-\mathrm{e}$ & $15.87 a$ & $16.37 a$ & $15.61 \mathrm{a}$ & \\
\hline \multicolumn{2}{|c|}{ Means of Iron } & $13.08 \mathrm{c}$ & $13.78 b$ & $14.26 a$ & & \\
\hline \multirow[t]{3}{*}{ Zinc $\times$ Iron } & 0 & $12.01 f$ & $12.55 \mathrm{e}$ & $13.13 d$ & & \\
\hline & 750 & $13.01 \mathrm{~d}$ & $13.75 \mathrm{c}$ & $14.21 \mathrm{~b}$ & Means of Copper & \\
\hline & 1500 & $14.23 b$ & $15.03 a$ & $15.43 a$ & & \\
\hline \multirow[t]{3}{*}{ Copper x Iron } & 0 & $12.15 f$ & $13.07 e$ & $13.59 \mathrm{~cd}$ & $12.94 \mathrm{c}$ & \\
\hline & 100 & $13.18 \mathrm{de}$ & $13.66 \mathrm{c}$ & $13.94 \mathrm{c}$ & $13.59 \mathrm{~b}$ & \\
\hline & 200 & $13.92 \mathrm{c}$ & $14.60 \mathrm{~b}$ & $15.24 a$ & $14.59 \mathrm{a}$ & \\
\hline
\end{tabular}

Means within a column, row and their interactions followed with the same letters are not significantly different from each other according to Duncan's multiple range tests at $5 \%$ level.

The results of the present study are in conformity with those of (Zhang and Brown 1999b; Tsipouridis et al. 2005; Kizilgoz et al., 2010; Ojeda-Barrios et al., 2014) on Pistachio trees. They detailed that foliar zinc application in different either form or concentrations enhanced zinc uptake which in turn was reflected in increasing leaf zinc concentration. Furthermore, Ghaderi, et al., (2003) reported that the foliar application of zinc was enhanced the nutritional status of 'Shahroodi' almond trees.

2- Copper content in leaves $\left(\mathrm{mg}_{\mathrm{kg}} \mathrm{kg}^{-1}\right)$

Data as shown in table (2) clear that zinc and iron, at second and third levels significantly increased copper content in leaves, compared with the control, while copper significantly increased copper content in leaves at third level at concentration $200 \mathrm{mg} . \mathrm{L}^{-1}$ which were $(13.29$ mg. $\left.\mathrm{kg}^{-1}\right)$.

Referring to the triple interactions, the highest copper content in leaves, (15.03 mg. $\left.\mathrm{kg}^{-1}\right)$ was obtained from the interactions of zinc (1500mg. $\mathrm{L}^{-1}$ ) plus copper (200mg. $\mathrm{L}^{-1}$ ) and iron (300mg. $\mathrm{L}^{-1}$ ), while the lowest copper content in leaves was obtained from the control (9.26 $\left.\mathrm{mg} \cdot \mathrm{kg}^{-1}\right)$.

Table (2): Effect of Foliar Spraying of Zinc, Copper and Iron and their interactions on copper content in leaves $\left(\mathbf{m g . k g}^{-1}\right)$ of pistachio cv. "Halebi"

\begin{tabular}{|c|c|c|c|c|c|c|}
\hline \multirow[t]{2}{*}{ Zinc mg.L-1 } & \multirow[t]{2}{*}{ Copper mg.L-1 } & \multicolumn{3}{|c|}{ Iron mg.L-1 } & \multirow[t]{2}{*}{ Zinc $\times$ Copper } & \multirow[t]{2}{*}{ Means of Zinc } \\
\hline & & 0 & 150 & 300 & & \\
\hline \multirow[t]{3}{*}{0} & 0.0 & $9.26 \mathrm{~h}$ & $12.29 \mathrm{c}-\mathrm{g}$ & $12.13 \mathrm{~d}-\mathrm{g}$ & $11.23 \mathrm{e}$ & $12.04 b$ \\
\hline & 100 & $11.49 \mathrm{~g}$ & $12.63 b-f$ & $12.66 \mathrm{~b}-\mathrm{f}$ & $12.26 \mathrm{~d}$ & \\
\hline & 200 & $11.89 \mathrm{e}-\mathrm{g}$ & $12.93 \mathrm{~b}-\mathrm{e}$ & $13.06 \mathrm{~b}-\mathrm{e}$ & $12.63 \mathrm{~cd}$ & \\
\hline \multirow[t]{3}{*}{750} & 0 & $12.06 \mathrm{~d}-\mathrm{g}$ & $12.69 b-f$ & $13.09 b-d$ & $12.62 \mathrm{~cd}$ & $13.00 \mathrm{a}$ \\
\hline & 100 & $12.23 \mathrm{c}-\mathrm{g}$ & $13.33 b c$ & $13.59 b$ & $13.05 b c$ & \\
\hline & 200 & $12.79 b-f$ & 13.53b & $13.66 \mathrm{~b}$ & 13.33b & \\
\hline
\end{tabular}




\begin{tabular}{|c|c|c|c|c|c|c|}
\hline \multirow[t]{3}{*}{1500} & 0 & $11.73 \mathrm{fg}$ & $12.79 b-f$ & $12.96 \mathrm{~b}-\mathrm{e}$ & $12.49 \mathrm{~cd}$ & \multirow[t]{3}{*}{ 13.13a } \\
\hline & 100 & $13.06 \mathrm{~b}-\mathrm{e}$ & $12.93 \mathrm{~b}-\mathrm{e}$ & $12.99 \mathrm{~b}-\mathrm{e}$ & $12.99 \mathrm{bc}$ & \\
\hline & 200 & $13.09 \mathrm{~b}-\mathrm{d}$ & $13.59 \mathrm{~b}$ & $15.03 a$ & $13.91 \mathrm{a}$ & \\
\hline \multicolumn{2}{|c|}{ Means of Iron } & $11.96 \mathrm{~b}$ & $12.97 a$ & $13.24 a$ & \multirow[b]{3}{*}{ Means of Copper } & \\
\hline \multirow[t]{3}{*}{ Zinc $\times$ Iron } & 0 & $10.88 \mathrm{~d}$ & $12.62 \mathrm{bc}$ & $12.62 b c$ & & \\
\hline & 750 & $12.36 \mathrm{c}$ & 13.18ab & $13.45 a$ & & \\
\hline & 1500 & $12.63 b c$ & $13.10 \mathrm{ab}$ & $13.66 a$ & & \\
\hline \multirow[t]{3}{*}{ Copper $\times$ Iron } & 0 & $11.02 \mathrm{e}$ & $12.59 \mathrm{~cd}$ & $12.73 \mathrm{~cd}$ & $12.11 \mathrm{c}$ & \\
\hline & 100 & $12.26 \mathrm{~d}$ & $12.96 \mathrm{bc}$ & $13.08 \mathrm{bc}$ & $12.77 \mathrm{~b}$ & \\
\hline & 200 & $12.59 \mathrm{~cd}$ & $13.35 b$ & $13.92 a$ & $13.29 a$ & \\
\hline
\end{tabular}

Means within a column, row and their interactions followed with the same letters are not significantly different from each other according to Duncan's multiple range tests at 5\% level.

The above results demonstrated positive effect of zinc, copper and iron foliar sprays on leaves copper concentration, the results are in agreements with Kallsen et al. (1998) they detailed that Copper spray significantly increased copper concentration of the leaf compared to control. However, foliar spray of iron (300 mg L-1) significantly increased the Fe concentration in pistachio leaves. Kallsen et al. (2000) also revealed that pistachio trees treated with zinc and copper increased leaves zinc and copper concentrations.

\section{3- Iron content in leaves ( $\left.\mathrm{mg} \cdot \mathrm{kg}^{-1}\right)$}

It is obvious from table (3) that foliar application of zinc and copper at second and third levels had a significant effect on iron content in leaves. While, iron application had no significant effect on leaves iron content when compared with control.

Referring to the interactions of the three studied factors, Results displayed that there were significant differences between the interactions of the three studied factors on leaves iron concentration. The interaction treatment of $1500 \mathrm{mg} . \mathrm{L}^{-1}$ zinc plus $200 \mathrm{mg} . \mathrm{L}^{-1}$ copper and $150 \mathrm{mg} . \mathrm{L}^{-1}$ iron besides, $1500 \mathrm{mg} . \mathrm{L}^{-1}$ zinc plus 200mg. $\mathrm{L}^{-1}$ copper and $300 \mathrm{mg} . \mathrm{L}^{-1}$ iron gave the highest value. The highest leaves iron content was (59.82 mg. $\mathrm{kg}^{-1}$ ) while the lowest value (49.45 mg. $\mathrm{kg}^{-1}$ ) was recorded from untreated treatment.

Table (3): Effect of Foliar Spraying of Zinc, Copper and Iron and their interactions on iron content in leaves (mg.kg ${ }^{-1}$ ) of pistachio cv. "Halebi"

\begin{tabular}{|c|c|c|c|c|c|c|}
\hline \multirow[t]{2}{*}{ Zinc mg.L-1 } & \multirow[t]{2}{*}{ Copper mg.L-1 } & \multicolumn{3}{|c|}{ Iron mg.L-1 } & \multirow[t]{2}{*}{ Zinc $\times$ Copper } & \multirow[t]{2}{*}{ Means of Zinc } \\
\hline & & 0 & 150 & 300 & & \\
\hline \multirow[t]{2}{*}{0} & 0.0 & $49.45 d$ & $51.12 \mathrm{~cd}$ & $52.53 \mathrm{~b}-\mathrm{d}$ & $51.04 \mathrm{c}$ & $54.46 b$ \\
\hline & 100 & $54.20 \mathrm{a}-\mathrm{d}$ & 54.96a-d & $55.29 \mathrm{a}-\mathrm{c}$ & $54.82 b$ & \\
\hline \multirow[t]{3}{*}{750} & 0 & $56.20 \mathrm{a}-\mathrm{c}$ & $56.86 a-c$ & $57.74 a b$ & $56.93 \mathrm{ab}$ & $57.60 \mathrm{a}$ \\
\hline & 100 & $56.56 a-c$ & $57.37 \mathrm{ab}$ & $57.90 \mathrm{ab}$ & $57.28 \mathrm{ab}$ & \\
\hline & 200 & $58.44 \mathrm{ab}$ & $58.66 \mathrm{ab}$ & $58.70 \mathrm{ab}$ & $58.60 \mathrm{a}$ & \\
\hline 1500 & 0 & $55.87 a-c$ & $56.53 a-c$ & 57.13a-c & $56.51 \mathrm{ab}$ & $57.90 \mathrm{a}$ \\
\hline \multirow[t]{3}{*}{ Zinc $\times$ Iron } & 0 & $53.50 \mathrm{c}$ & $54.44 \mathrm{bc}$ & $55.44 a-c$ & & \\
\hline & 750 & $57.07 \mathrm{ab}$ & $57.63 \mathrm{ab}$ & $58.11 \mathrm{a}$ & Means of Copper & \\
\hline & 1500 & $57.35 \mathrm{ab}$ & $57.86 \mathrm{ab}$ & $58.51 \mathrm{a}$ & & \\
\hline \multirow[t]{3}{*}{ Copper $\times$ Iron } & 0 & $53.84 c$ & $54.84 \mathrm{bc}$ & $55.80 \mathrm{a}-\mathrm{c}$ & $54.83 b$ & \\
\hline & 100 & $56.10 \mathrm{a}-\mathrm{c}$ & $56.89 \mathrm{a}-\mathrm{c}$ & $57.26 \mathrm{ab}$ & $56.75 a$ & \\
\hline & 200 & $57.98 \mathrm{ab}$ & $58.20 \mathrm{ab}$ & $59.01 a$ & $58.39 \mathrm{a}$ & \\
\hline
\end{tabular}


Means within a column, row and their interactions followed with the same letters are not significantly different from each other according to Duncan's multiple range tests at $5 \%$ level.

The findings of Norozi, et al., (2019) demonstrated that zinc foliar application, alone or in combination, increased leaf concentrations of $\mathrm{Zn}, \mathrm{Fe} \mathrm{K}, \mathrm{P}, \mathrm{Mg}$, and $\mathrm{Mn}$. In pistachio, it was noticed that there is an antagonistic influence between $\mathrm{Zn}$ and $\mathrm{Fe}, \mathrm{Mn}$ and $\mathrm{Cu}$, because the concentration of $\mathrm{Fe}$ was considerably higher in $\mathrm{Zn}$-deficient trees, application of $\mathrm{Zn}$ decreased concentrations of $\mathrm{Fe}$ (Shahriaripour and Tajabadipour, 2010).

\section{2-Fruit set}

\section{1-Primary fruit set \%}

Data as shown in (Table4) cleared that all treatment significantly increased Primary fruit set in comparison with control. Highest Primary fruit set was obtained from the trees received $\mathrm{Zn}$ (39.49\%), $\mathrm{Cu}(39.20 \%)$ and $\mathrm{Fe}(39.52 \%)$ each alone, while the lowest primary fruit set was obtained from the control.

The same table also points the significant effect of interaction among the three studied factors, the maximum value (49.32\%) was obtained from combination of $1500 \mathrm{mg} \cdot \mathrm{L}^{-1} \mathrm{zinc}$ x $200 \mathrm{mg} . \mathrm{L}^{-1}$ copper and $300 \mathrm{mg} . \mathrm{L}^{-1}$ iron compared to lowest value $(25.45 \%)$ was obtained from $0 \mathrm{mg} . \mathrm{L}^{-1} \mathrm{zinc}$ x $0 \mathrm{mg} . \mathrm{L}^{-1}$ copper and $\quad 0 \quad \mathrm{mg} . \mathrm{L}^{-1} \quad$ iron.

Table (4): Effect of Foliar Spraying of Zinc, Copper and Iron and their interactions on primary fruit set\% of pistachio cv. "Halebi"

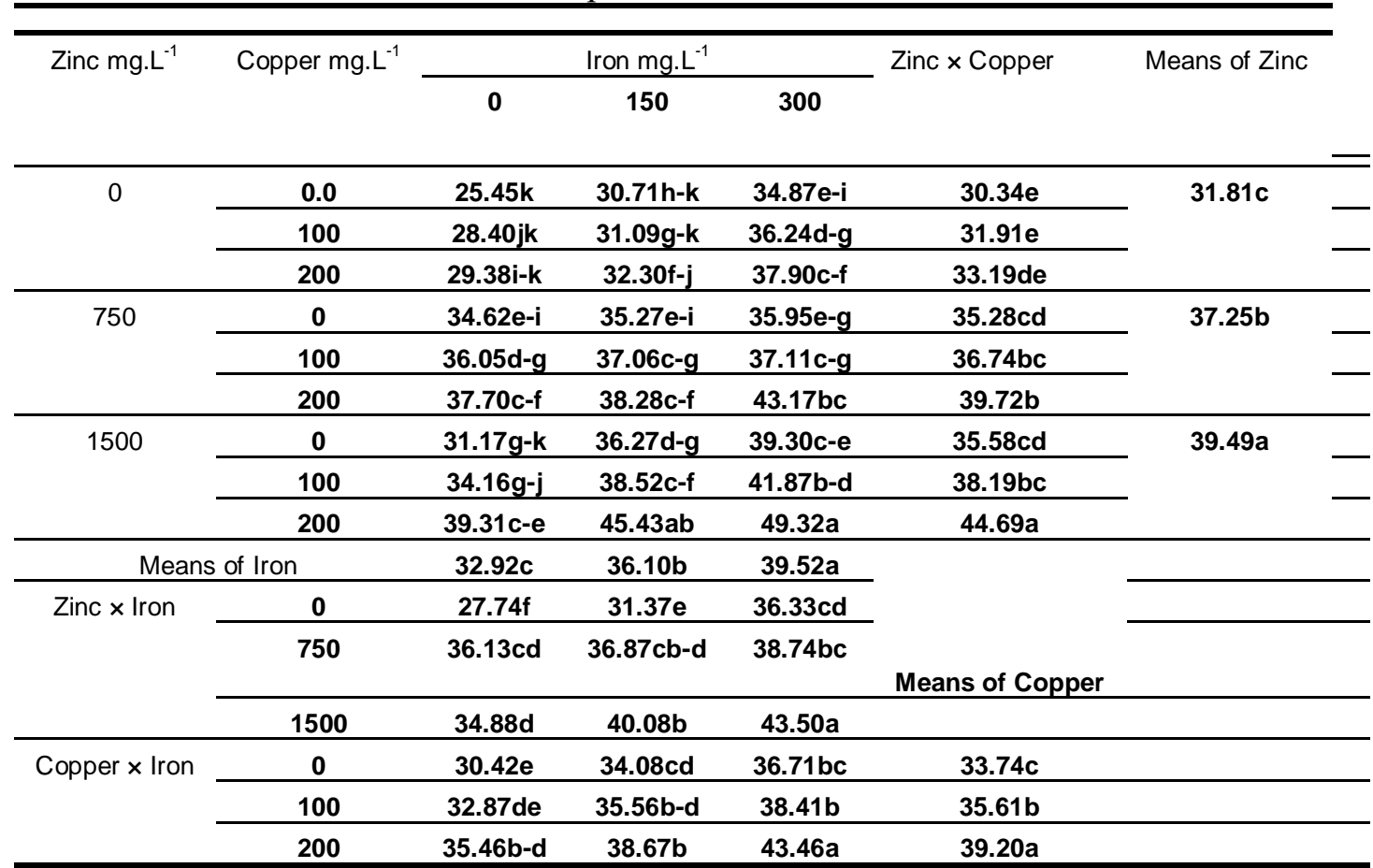

Means within a column, row and their interactions followed with the same letters are not significantly different from each other according to Duncan's multiple range tests at $5 \%$ level.

The present results are in agreement with the finding obtained by (Baninasab, et al., 2007; Ranjbar Kabotarkhani et al. 2009) they concluded that zinc and copper treatments increased primary fruit set in pistachio trees.

\section{2-Final fruit set \%}

Table (5) illustrated that the spraying Halebi pistachio trees with $1500 \mathrm{mg} . \mathrm{L}^{-1}$ zinc, 200 $\mathrm{mg} . \mathrm{L}^{-1}$ copper and $300 \mathrm{mg} . \mathrm{L}^{-1}$ iron significantly increased the percentage of final fruit set which gave the highest value $(22.81 \%, 22.28 \%$ and $21.48 \%$ ) respectively.

In respect, the interaction of the three study factors, the interaction of $1500 \mathrm{mg} . \mathrm{L}^{-1}$ zinc, 200 mg. $\mathrm{L}^{-1}$, copper and $300 \mathrm{mg} . \mathrm{L}^{-1}$ iron gave the highest value $(27.32 \%)$ compared to lowest value $(14.36 \%)$ from untreated (control) trees 
Table (5): Effect of Foliar Spraying of Zinc, Copper and Iron and their interactions on Final fruit set $\%$ of pistachio cv. "Halebi"

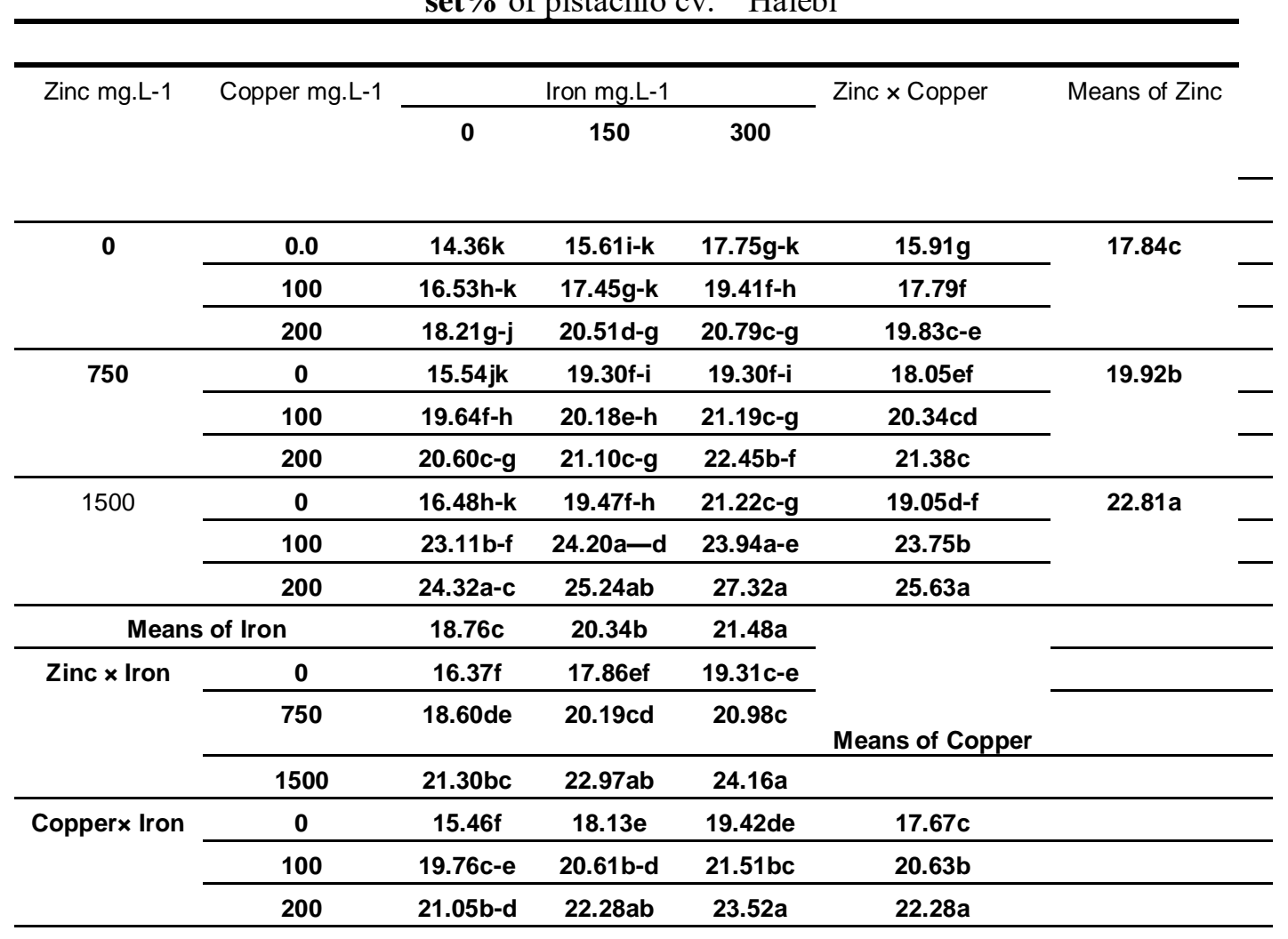

Means within a column, row and their interactions followed with the same letters are not significantly different from each other according to Duncan's multiple range tests at $5 \%$ level.

The presented results could be supported by (Soliemanzadeh et al., 2013) They investigate that foliar application of iron, zinc and copper on fruit quantity and quality of pistachio trees in different concentrations, increased the first and final fruit set as compared with control. The effect of $\mathrm{Zn}$ and $\mathrm{Fe}$ on fruit set was supported by Abd El Motty et al. (2006), they reported foliar application of $\mathrm{Zn}$ and $\mathrm{Fe}$ increased primary and final fruit set in citrus trees. Baybordi and Malakouti (2009) revealed that foliar application of $\mathrm{Zn}$ increased the final fruit set of pistachio trees. In addition, Zn-deficiecy lead to the number of nuts per cluster dramatically decreased and most of them can be blanks (Beede et al. 2005).

\section{3- Yield per shoot (g)}

As shown in table (6) all treatment significantly increased yield per shoot. So increasing the levels of zinc up to $\left(1500 \mathrm{mg} . \mathrm{L}^{-1}\right)$ , copper to (200 mg. $\left.\mathrm{L}^{-1}\right)$ and iron to (300 mg. $\mathrm{L}^{-1}$ ) lead to significant increase in yield which were $(127.08 \mathrm{~g}, 114.18 \mathrm{~g}, 113.75 \mathrm{~g})$ respectively.

In respect with the interactions of the three studied factors, the maximum value was $(144.21 \mathrm{~g})$ at the interactions of third level of each treatment, whereas the minimum value was happened (63.35g) with untreated trees. 
Table (6): Effect of Foliar Spraying of Zinc, Copper and Iron and their interactions on Yield/ shoot (g) of pistachio cv. "Halebi"

\begin{tabular}{|c|c|c|c|c|c|c|}
\hline \multirow[t]{2}{*}{ Zinc mg.L-1 } & \multirow[t]{2}{*}{ Copper mg.L-1 } & \multicolumn{3}{|c|}{ Iron mg.L-1 } & \multirow[t]{2}{*}{ Zinc $\times$ Copper } & \multirow[t]{2}{*}{ Means of Zinc } \\
\hline & & 0 & 150 & 300 & & \\
\hline \multirow[t]{3}{*}{0} & 0.0 & 63.351 & $71.87 \mathrm{k}$ & $88.30 \mathrm{ij}$ & $74.51 \mathrm{~g}$ & $84.54 \mathrm{c}$ \\
\hline & 100 & $81.86 j$ & $89.89 \mathrm{ij}$ & $90.80 \mathrm{ij}$ & $87.51 f$ & \\
\hline & 200 & $88.79 \mathrm{ij}$ & $91.77 i$ & $94.27 \mathrm{hi}$ & $91.61 f$ & \\
\hline \multirow[t]{3}{*}{750} & 0 & $96.48 \mathrm{hi}$ & $101.41 \mathrm{gh}$ & $111.60 \mathrm{f}$ & $103.16 \mathrm{e}$ & $109.16 b$ \\
\hline & 100 & $100.61 \mathrm{gh}$ & $109.15 \mathrm{fg}$ & $115.58 \mathrm{ef}$ & $108.45 d$ & \\
\hline & 200 & $102.69 \mathrm{gh}$ & $117.99 d-f$ & $126.89 \mathrm{~b}-\mathrm{d}$ & $115.86 \mathrm{c}$ & \\
\hline \multirow[t]{3}{*}{1500} & 0 & 116.13ef & $121.82 \mathrm{c}-\mathrm{e}$ & 122.71b-e & $120.22 \mathrm{C}$ & $127.08 \mathrm{a}$ \\
\hline & 100 & $125.78 b-d$ & $122.61 \mathrm{~b}-\mathrm{e}$ & $129.42 \mathrm{bc}$ & $125.94 b$ & \\
\hline & 200 & $129.78 b c$ & $131.26 \mathrm{ab}$ & 144.21a & $135.08 \mathrm{a}$ & \\
\hline \multicolumn{2}{|c|}{ Means of Iron } & $100.61 \mathrm{c}$ & $106.42 b$ & $113.75 a$ & \multirow{3}{*}{ Means of Copper } & \\
\hline \multirow[t]{3}{*}{ Zinc $\times$ Iron } & 0 & $78.00 \mathrm{~h}$ & $84.51 \mathrm{~g}$ & $91.13 f$ & & \\
\hline & 750 & $99.93 \mathrm{e}$ & $109.52 d$ & $118.03 c$ & & \\
\hline & 1500 & $123.90 \mathrm{~b}$ & $125.23 b$ & $132.11 a$ & & \\
\hline \multirow[t]{3}{*}{ Copper $\times$ Iron } & 0 & $91.99 f$ & $98.37 \mathrm{e}$ & $107.54 \mathrm{~cd}$ & $99.30 \mathrm{c}$ & \\
\hline & 100 & 102.75de & $107.22 \mathrm{~cd}$ & $111.93 \mathrm{bc}$ & $107.30 \mathrm{~b}$ & \\
\hline & 200 & $107.09 \mathrm{c}$ & $113.67 b$ & $121.79 a$ & $114.18 \mathrm{a}$ & \\
\hline
\end{tabular}

Means within a column, row and their interactions followed with the same letters are not significantly different from each other according to Duncan's multiple range tests at $5 \%$ level.

Combination among all the micronutrients application significantly increase yield of the pistachio trees may be because of the important roles of zinc in growth promoting substances (Shivanandam et al., 2007), cupper for the activities of certain enzymes which are beneficial in cell growth (Kallsen et al. 2000) and iron in electron transport chain (Meshcheryakov and Alekhina (1971)). Our results demonstrated that the combination among micronutrients significantly increased final fruit set and thus fruit yield, Sotomayor et al. (2000), and Pandit, et al., (2008) they revealed that the combination among studied treatments significantly increase final fruit set in trees. This increase in fruit set and yield might be attributed to the best possible development of pollen tube, adequate levels of nutrients in pollen grain, also an increase in duration of pollination time. It was revealed that foliar application of zinc sulfate (1 and $2 \mathrm{~g} \mathrm{~L}$-1) increased yield of pistachio (Kizilgoz et al. 2010). Also Soliemanzadeh et al.
(2014) reported that the foliar application of zinc and copper on pistachio trees at high levels, significantly increased primary and final fruit set, yield and yield quality when compared with control. Kizilgoz, et al.,(2010) investigate that an increased fruit yield of pistachio trees from zinc application as a result of increased leaves zinc content.

\section{4- Blank Nuts \%}

Obtained results in table (7) showed that all of the treatments decreased the percentage of blank nuts, as compared with untreated trees in control treatment. High concentration of zinc 1500mg. $\mathrm{L}^{-1}$, 200mg. $\mathrm{L}^{-1}$ copper and 300mg.. $\mathrm{L}^{-1}$ iron each alone reduced the percentage of blank nuts which were $(10.92 \%, 10.73 \%, 9.76 \%)$ respectively.

Regarding to the triple interactions, the interactions of $1500 \mathrm{mg} . \mathrm{L}^{-1}$ zinc, $200 \mathrm{mg} . \mathrm{L}^{-1}$ copper with $300 \mathrm{mg} . \mathrm{L}^{-1}$ iron appeared to be the most operative which were $(9.76 \%)$. 
Table (7): Effect of Foliar Spraying of Zinc, Copper and Iron and their interactions on Blank nuts\% of pistachio cv. "Halebi"

\begin{tabular}{|c|c|c|c|c|c|c|}
\hline \multirow[t]{2}{*}{ Zinc mg.L-1 } & \multirow[t]{2}{*}{ Copper mg.L-1 } & \multicolumn{3}{|c|}{ Iron mg.L-1 } & \multirow[t]{2}{*}{ Zinc $\times$ Copper } & \multirow[t]{2}{*}{ Means of Zinc } \\
\hline & & 0 & 150 & 300 & & \\
\hline \multirow[t]{3}{*}{0} & 0.0 & $13.12 \mathrm{a}$ & $13.04 a b$ & $12.77 a-c$ & $12.98 \mathrm{a}$ & $12.19 \mathrm{a}$ \\
\hline & 100 & $12.68 \mathrm{a}-\mathrm{d}$ & 12.05a-f & $11.72 \mathrm{c}-\mathrm{g}$ & $12.15 b$ & \\
\hline & 200 & $11.66 \mathrm{c}-\mathrm{g}$ & $11.44 \mathrm{e}-\mathrm{h}$ & $11.25 \mathrm{e}-\mathrm{h}$ & $11.45 \mathrm{~cd}$ & \\
\hline \multirow[t]{3}{*}{750} & 0 & 12.72a-d & $12.18 \mathrm{a}-\mathrm{e}$ & $12.00 \mathrm{~b}-\mathrm{f}$ & $12.30 \mathrm{~b}$ & $11.51 \mathrm{~b}$ \\
\hline & 100 & $11.68 \mathrm{c}-\mathrm{g}$ & $11.57 \mathrm{~d}-\mathrm{g}$ & $11.35 \mathrm{e}-\mathrm{h}$ & $11.53 \mathrm{~cd}$ & \\
\hline & 200 & $11.01 \mathrm{f}-\mathrm{h}$ & $10.62 \mathrm{~g}-\mathrm{i}$ & $10.50 \mathrm{hi}$ & $10.71 \mathrm{e}$ & \\
\hline \multirow[t]{3}{*}{1500} & 0 & $11.85 c-f$ & $11.72 \mathrm{c}-\mathrm{g}$ & $11.65 \mathrm{c}-\mathrm{g}$ & $11.74 \mathrm{bc}$ & $10.92 \mathrm{c}$ \\
\hline & 100 & 11.42 & $10.94 f-h$ & $10.57 \mathrm{~g}-\mathrm{i}$ & $10.98 \mathrm{de}$ & \\
\hline & 200 & $10.57 \mathrm{~g}-\mathrm{i}$ & $9.77 \mathrm{i}$ & $9.76 \mathrm{i}$ & $10.03 f$ & \\
\hline \multicolumn{2}{|c|}{ Means of Iron } & $11.86 a$ & $11.48 \mathrm{~b}$ & $11.28 \mathrm{~b}$ & & \\
\hline \multirow[t]{3}{*}{ Zinc $\times$ Iron } & 0 & $12.49 a$ & 12.17ab & $11.91 \mathrm{a}-\mathrm{c}$ & & \\
\hline & 750 & $11.80 \mathrm{~b}-\mathrm{d}$ & $11.46 \mathrm{~cd}$ & $11.28 \mathrm{de}$ & Means of Copper & \\
\hline & 1500 & $11.28 \mathrm{de}$ & 10.81 ef & $10.66 f$ & & \\
\hline \multirow[t]{3}{*}{ Copper× Iron } & 0 & $12.56 a$ & $12.31 \mathrm{ab}$ & 12.14ab & $12.34 a$ & \\
\hline & 100 & $11.93 b c$ & $11.52 \mathrm{~cd}$ & $11.21 d$ & $11.55 \mathrm{~b}$ & \\
\hline & 200 & $11.08 \mathrm{de}$ & $10.61 \mathrm{e}$ & $10.50 \mathrm{e}$ & $10.73 c$ & \\
\hline
\end{tabular}

Means within a column, row and their interactions followed with the same letters are not significantly different from each other according to Duncan's multiple range tests at $5 \%$ level.

In this study, micro nutrient treatments had a significant effect on the percentage of blankness, the results are in conformity with Norozi, et al., (2019) they found that nutrient treatments had significant effects on the percentage of blankness.

\section{CONCLUSION}

Foliar application of Zinc, Copper and Iron as foliar spray in bud swell stage and green tip stage significantly influenced leaf nutrients, fruit yield and the percentage of blankness of pistachio trees. It can be concluded that in the calcareous soils, foliar spray of Zinc, Copper and Iron fertilizers is essential for obtaining better fruit yield and quality in pistachio.

\section{REFRENCESES}

Abd El Motty, Z.E., Shahin, M.F.M., Hagagg, L.F. (2006): Response of Valencia oranges trees budded on Troyer citrange and Sour orange to foliar application of some macro and micro nutrients. J. Appl. Sci. Res. 2(11): 952-965.

Alvarez-Fernandez, A., Garcia-Lavina, P., Fidalgo, J., Abadia J. and Abadia A. (2004). Foliar fertilization to control iron cholorosis in pear (Pyrus communis L.) trees. Plant Soil, 263: 515.

Baninasab, B., M. Rahemi and H. Shariatmadari. 2007. Seasonal change in mineral content of different organs in the alternate bearing of pistachio trees. Communications in Soil Science and Plant Analysis 38:241-258.

Beede, R.H., Brown, P.H., Kallsen, C., Weinbaum, S.A. (2005): Diagnosing and correcting nutrient deficiencies. In: L. Ferguson (ed), Pistachio production manual. 4th edition.Division of Agriculture and Natural Resources. University of California: Oakland. Pp: 147-157.

Bhargava, B. and Raghupathi, H. (1993). Analysis of plant materials for macro and micronutrients. Methods of analysis of soil, plant, water and fertilizers. Fertilizers Development and Consultation Organization, New Delhi, India. 4(3): 49-82.

Bybordi, A., Malakouti, M.J. (2009): Effects of N, Zn and $\mathrm{B}$ foliar application in increasing fruit set and yield of pistachio in East Azerbaijan. 5th 
International Symposium on Pistachio and Almond, Turkey. pp:260.

Chaturvedi, OP, Singh, AK, Tripathi, VK and Dixit, AK (2005) Effect of zinc and iron on growth, yield and quality of strawberry cv. Chandler. Acta Hortic. 696: 237-240.

Einali, A. and Valizadeh, J., (2017). Storage reserve mobilization, gluconeogenesis, and oxidative pattern in dormant pistachio (Pistacia vera L.) seeds during cold stratification. Trees, 31(2), pp.659-671.

Ghaderi N, Vezvaei A, Talaei AR, Babalar M (2003) Effect of boron and zinc foliar spraying as well as concentrations of these elements on some leaf and fruit characteristics of almond. Iranian J Agric Sci 34: 127-135.

Gursoz, S., Gokoglu, S. and Ak, B.N., (2010). Determination of mineral nutrition contents of grape and pistachio cultivars grown as inter planted orchard. Options Mediterraneennes, 94, pp.25-30.

Javanshah, A., Alipour, H. and Hadavi, F., (2005). A model for assessing the chill units received in Kerman and Rafsanjan areas. In $I V$ International Symposium on Pistachios and Almonds 726 (pp. 221-226).

Kallsen, C.E., Holtz, B.A., Wylie, C., Villaruz, L. (1998): Injecting zinc and copper fertilizers through low volume irrigation systems to meet pistachio nutrient requirements. In: Calif. Pistachio Ind. Ann. Rpt. pp: 105-106.

Kallsen, C.E., Holtz, B.A., Wylie, C., Villaruz, L. (2000): Injecting zinc and copper fertilizers through low volume irrigation systems to meet pistachio nutrient requirements. In: Calif. Pistachio Ind. Ann. Rpt. pp: 105-106

Keshavarz, K., Vahdati, K., Samar, M., Azadegan, B., \& Brown, P. H. (2011). Foliar application of zinc and boron improves walnut vegetative and reproductive growth. HortTechnology, 21(2), 181-186.

Kizilgoz I, Sakin E, Aslant N. (2010). The effect of zinc fertilization on the yield of Pistachio (Pistacia vera L.) grown under rainfed condition. African Journal of Agricultural Research 5, 3427-3430.

Meshcheryakov, AM and Alekhina, LA (1971) The effect of iron sulphate and chelate on chlorosis and yields in irrigated grape vines grown on calcareous soil. Trudy-Issledovaniya-Biologii-
Agrotekhniki-i-Uslovii - Vyraschivaniya Nekotorykh-Sel Skokhozyoi - stvennykhKoltur-Tadzhikistapa, 15: 90-104.

Mozafari, V. (2005): The role of potassium, calcium and zinc in controlling pistachio dieback. Ph.D. Thesis, Tarbiat Modarres University, Tehran, Iran. (in Persian).

Najad, A.H. (2004): Effect of zinc and iron on growth, yield and quality of pistachio M.Sc. Thesis, Azadi University, Tehran, Iran. (in Persian).

Norozi, M., ValizadehKaji, B., Karimi, R. and Nikoogoftar Sedghi, M., (2019). Effects of foliar application of potassium and zinc on pistachio (Pistacia vera L.) fruit yield. International Journal of Horticultural Science and Technology, 6(1), pp.113-123.

Ojeda-Barrios D.L, Perea-Portillo E, HernándezRodríguez O.A, Martínez-Téllez J, Abadía J, Lombardini L. (2014). Foliar fertilization with zinc in pecan trees. HortScience 49, 562-566.

Pandit, A. H., Wani, M. S., Mir, M. A., Bhat, K. M., Wani, S. M., \& Malik, A. R. (2008, August). Effect of foliar application of boron and zinc on fruit set and productivity of almond. In $I X$ International Symposium on Integrating Canopy, Rootstock and Environmental Physiology in Orchard Systems 903 (pp. 10071009).

Ranjbarkabotarkhani, H.R., Mohamadialiabadi, H., Hokmabadi, H. (2009): Effect of some commercial fertilization of zinc, calcium and copper chelate on pistachio fruit set. 5th International Symposium on Pistachio and Almond, Turkey. pp:260.

Razzaq, K., Khan, A.S., Malik, A.U, Shahid, M. and Ullah, S. (2013) Foliar application of Zinc influences the leaf mineral status, vegetative and reproductive growth, yield and fruit quality of "Kinnow" mandarin. Journal of Plant Nutrition, 36, 1479- 1495.

Rosati, A., Zipanćič, M., Caporali, S. and Paoletti, A., (2010). Fruit set is inversely related to flower and fruit weight in olive (Olea europaea L.). Scientia horticulturae, 126(2), pp.200204.

SAS Institute. (2015). Base SAS 9.4 procedures guide. SAS Institute.

Shahriaripour R, Tajabadipour A. (2010). Zinc nutrition of pistachio: interaction of zinc with 
other trace elements. Communications in Soil Science and Plant Analysis 41, 1885-1888.

Shivanandam, VN, Pradeep, SL, Rajanna, KM and Shivappa. (2007) Effect of zinc sulphate on growth and yield of mango varieties and hybrids. J. Soil Crops, 17: 225-229.

Shoeib, MM. and El sayed, A (2003) Response of "Thompson Seedless" grape vines to the spray of some nutrients and citric acid. Minia J. Agric. Res. Dev. 23(4): 681-698.

Soliemanzadeh, A.; Mozafari, V. and Kamali, M. (2014). Treatment of Pistachio Trees with Zinc and Copper in Time of Swollen Bud in Two Consecutive Years. Communications in soil science and plant analysis. 45(8): 10251036.

Soliemanzadeh, A. (2012): Study effects of foliar application zinc, iron and copper on fruit set of pistachio trees. MSc Thesis, Vali-E-Asr University of Rafsanjan, Iran. (in Persian).

Soliemanzadeh, A.; Mozafari, V.; Pour, A.T. and Akhgar, A. (2013). Effect of $\mathrm{Zn}, \mathrm{Cu}$ and $\mathrm{Fe}$ foliar application on fruit set and some quality and quantity characteristics of Pistachio trees. South Western Journal of Horticulture, Biology and Environment. 4(1): 19-34.

Sotomayor, C., Silva, H. and Castro, J. (2000). Effectiveness of boron and zinc foliar sprays on fruit setting of two Almond cultivars. Acta Hort. 591:129-132.

Tavallali, V. and Rahemi, M., (2007). Effects of rootstock on nutrient acquisition by leaf, kernel and quality of pistachio (Pistacia vera L.). American-Eurasian Journal of Agricultural and Environmental Science, 2(3), pp. 240-246.

Tavallali, V., Rahemi, M. (2007): Effect of rootstock on nutrient acquisition by leaf, kernel and quality of pistachio (Pistacia vera L.). American-Eurasian J. Agric. Environ. Sci. 2(3): 240-246.

Tsipouridis, C., Thomidis, T., Zakinthinos, I., Michilidis, Z., Michaillides, T. (2005): Treatment of pistachio with boric acid, znsulfate and zn-chelate. Agronomy for Sustainable Development. 25:377-379.

Wang, S., Li, M., Tian, X., Li, S., Chen, Y., Jia, Z., ... \& Zhao, A. (2016). Zinc and iron concentrations in grain milling fractions through combined foliar applications of $\mathrm{Zn}$ and macronutrients. Field Crops Research, 187, 135-141.

Zhang, Q., Brown, P. (1999b): The mechanism of foliar zinc adsorption in pistachio and walnut. J. Am. Soc. Hortic. Sci. 124:312-317. 